\author{
Марія Сотер, \\ кандидат педагогічних наук, \\ кораблебудування імені адмірала Макарова \\ (м. Первомайськ, Україна) \\ Mariia Soter, \\ Ph.D. in Pedagogical Sciences, \\ Lecturer of the Department of Social \\ and Humanitarian Disciplines, \\ Pervomaisk Branch of Admiral Makarov \\ National University of Shipbuilding \\ (Pervomaisk, Ukraine) \\ sotermariia@gmail.com \\ ORCID ID 0000-0000-0002-4626-0137
}

викладач кафедри соціально-гуманітарних дисциплін, Первомайська філія Національного університету

Удк 378.141

\title{
ВІДЕОКОНФЕРЕНЦІЯ ЯК ЗАСІБ ІНШОМОВНОЇ ПІДГОТОВКИ СТУДЕНТІВ
}

Анотація. У статті наголошено на актуальності впровадження відеоконференції в освітній процес закладів вищої освіти, що дає змогу оптимізувати як аудиторну, так і позааудиторну іншомовну підготовку студентів. Метою статті є дослідження відеоконференції як засобу іншомовної підготовки студентів. Для досягнення мети наукового дослідження використано комплекс методів: аналіз та систематизація для виокремлення представленої проблеми на сучасному етапі; метод узагальнення для представлення переваг імплементації відеоконференцій в освітній процес закладів вищої освіти.

Акцентовано, що до переваг використання відеоконференцій з метою іншомовної підготовки студентів закладів вищої освіти належить: створення рівних можливостей доступу до взаємодії студентів та викладачів (зокрема, комунікативної взаємодії іноземною мовою) незалежно від місця їх перебування в зручний для кожного учасника вебконференції час; реалізація студентоцентрованого навчання і викладання, у межах якого всі зусилля спрямовуються на забезпечення кожного студента окремо і всіх разом необхідною інформацією в режимі онлайн; наявність постійного зворотного зв'язку між усіма суб'єктами освітнього процесу (як завдяки діалогу між учасниками в ході конференції, так і шляхом залучення під час конференції чату); розширення доступу до освітніх ресурсів за наставництва викладача й обміну інформацією онлайн; гнучкість для того, хто навчається, внаслідок можливості цілодобового доступу до інформації в режимі реального часу (у будь-який час і в будь-якому місці); візуалізація освітнього процесу онлайн (бачити, чути співрозмовника (як викладача, так і всіх студентів), а також пропоновану викладачем інформацію, активно комунікувати, що важливо для іншомовної підготовки); одночасне залучення значного числа учасників із різних регіонів України і зарубіжжя.

Ключові слова: відеоконференція, програма Skype, програма Zoom, месенджер Discord, додаток до мобільного телефону Viber, програма Messenger.

\section{VIDEOCONFERENCE AS A MEANS OF STUDENTS' FOREIGN LANGUAGE TRAINING}

Abstract. The relevance of the implementation of videoconference in the educational process of higher education institutions has been emphasized. It has been noted that videoconference gives an opportunity to optimize both classroom and extracurricular students' foreign language training. The aim of the article is to study the videoconference as a means of students' foreign language training.

To achieve the aim of scientific research, a set of methods has been used such as the method of analysis and systematization - to identify the problem at the present stage; the method of generalization - to represent the benefits of implementing videoconferencing in the educational process of higher education institutions.

It has been emphasized that the advantages of using videoconferencing for students' foreign language training of higher education institutions include: the creation of equal opportunities for access to interaction of students and lecturers (in particular, communicative interaction in the foreign language) regardless of their location at a suitable period of time for each participant of the conference; the implementation of student-centered learning and teaching, within which all efforts are aimed at providing each student individually and all together with the necessary information online; the availability of constant feedback among all subjects of the educational process (both through the dialogue among participants during the videoconference and with the help of engaging in chat during the conference); the expanding access to educational resources under the lecturer's guidance and the exchange of information online; flexibility for the learner, due to the possibility of round-the-clock access to information in real time (anytime and anywhere); the visualization of the educational process online (see, hear the interlocutor, both the lecturer and all students, as well as the information offered by the lecturer, actively communicate; all these factors are important for foreign language training); simultaneous involvement of a significant number of participants from different regions of Ukraine and abroad.

Keywords: web conference; Skype program; Zoom program; Discord Messenger; Viber mobile phone application; Messenger program. 


\section{ВСТУП}

Постановка проблеми. Нові виклики, що постали перед іншомовною підготовкою висококваліфікованих фахівців закладів вищої освіти, вимагають термінових нагальних кроків щодо їх швидкого розв'язання, зокрема й через упровадження різного роду ефективних новітніх засобів навчання, одним із яких $є$ відеоконференція. Відзначмо, що врегулювання питань, які пов'язані з іншомовною підготовкою студентів закладів вищої освіти України, здійснюються з урахуванням Законів України «Про освіту» (2017), «Про вищу освіту» (2014), «Про професійно-технічну освіту» (1998), Рекомендацій N R (98) 6 Комітету Міністрів Ради Європи «Про сучасні мови» (1998), «Про національну програму інформатизації» (1998), Національної доктрини розвитку освіти (2002), Загальноєвропейських рекомендацій з мовної освіти (Страсбург, 2003), Програми з англійської мови для професійного спілкування (2005) та ін.

Аналіз наукових досліджень і публікацій. Дослідження можливостей імплементації відеоконференції в освітній процес закладів вищої освіти є предметом розгляду як вітчизняних, так і зарубіжних науковців, різні аспекти цієї проблеми представили у своїх працях В. Биков, О. Глазунова, Л. Дідух, І. Задорожна, І. Козубовська, Л. Лисенко, А. Приходько, О. Словінська, Р. Шаран, Б. Шуневич, L. Basko, B. S. Bloom, M. S. Cohen, R. L. DeMichiell, J. Hartman, R. D. Manning, та ін.

\section{МЕТА I ЗАВДАННЯ ДОСЛІДЖЕННЯ}

Метою наукової розвідки є аналіз відеоконференції як засобу іншомовної підготовки студентів.

\section{МЕТОДИ ДОСЛІДЖЕННЯ}

Для досягнення мети наукового дослідження використано комплекс методів: аналіз та систематизація для виокремлення представленої проблеми на сучасному етапі; метод узагальнення для представлення переваг імплементації відеоконференцій в освітній процес закладів вищої освіти.

\section{РЕЗУЛЬТАТИ ДОСЛІДЖЕННЯ}

Реалізація навчання через відеоконференцію дає можливість синхронізувати освітній процес (Basko L., Hartman J., 2017, с. 24). Л. Басько, Дж. Хартман відзначають, що відеоконференції дають змогу викладачеві взаємодіяти з кількома студентами одночасно, а також з кожним студентом окремо, що сприяє досягненню їх індивідуального успіху в навчанні. Понад те, імплементація відеоконференції в освітній процес закладів вищої освіти сприяє оптимізації як аудиторної, так і позааудиторної роботи студентів.

За визначенням І. Задорожної, відеоконференція - це «нтернет-технологія, спрямована на підтримку багатостороннього діалогу реального часу» (Задорожна І., 2013, с. 62). Зазначається, що відеоконференція «відрізняється від чату більш досконалою системою ідентифікації учасників діалогу і використанням мультимедійних матеріалів - презентацій, аудіозаписів тощо ... під час відеоконференції формами передачі інформації є не лише текст, як у випадку з чатом, а й статичне, динамічне зображення, звук». Так, можливість бачити один одного під час вебконференції дає змогу налаштувати всіх суб'єктів освітнього процесу (як викладача, так і студентів) на ефективну комунікативну взаємодію задля досягнення спільної мети і поставлених завдань, оптимізує та активізує їх співпрацю і співучасть, уможливлює підтримувати зоровий контакт з усіма учасниками вебконференції, що налаштовує їх на творчу і доброзичливу атмосферу.

Л. Лисенко виокремлює поняття «відеоконференція» як «інтерактивний інструмент, який включає аудіо, відео, комп'ютерні технології для здійснення зв'язку віддалених територіально співрозмовників «обличчям до обличчя» в реальному часі» (Лисенко Л. О., 2019, с. 127). Дослідниця відносить його до виду онлайн навчання. Відеоконференція при вивченні іноземної мови дає змогу «формувати свідоме ставлення і розгляд висунених проблем у термінології, активність в її обговоренні, мовну культуру тощо. Співрозмовники мають можливість бачити вираз обличчя і мову жестів, ці речі $є$ найважливішими аспектами спілкування, які втрачаються при асинхронних видах роботи (е-таil, чат, форум, блог)». Відеоконференція дає можливість «об'єднувати разом різні групи студентів з різних вишів для спільного обговорення».

Л. Дідух наголошує, що «відеоконференцзв'язок є інструментом електронного навчання (E-learning)», що сприяє проведенню таких форм організації освітнього процесу, як лекції, семінари, індивідуальні консультації, іспити, заліки тощо, відеоконференції використовуються також «для зустрічей, презентацій у мережі Інтернет, що підключений до інших учасників конференції за технологією «клієнт-сервер» через мережу Інтернет» (Дідух Л. І., 2012, с. 256). Дослідниця до недоліків проведення вебконференції відносить їх обмеженість, що «полягає в тому, що всі учасники відеоконференції мають бути підключеними до Інтернет».

Значною перевагою відеоконференції $€$ те, що вона «забезпечує практично таку саму ефективність взаємодії просторово розділених користувачів, як і при їх особистій зустрічі в одній аудиторії» (Жарких Ю. С., Лисоченко С. В., Сусь Б. Б., Третяк О. В., 2012, с. 155). Відеоконференції подіяють на декілька видів: студійні відеоконференції (проводять звичайно з одностороннім відеозв'язком), групові та персональні (двосторонній відеозв'язок) (там само, с. 155-160).

А. Приходько серед інших переваг застосування відеоконференції визначає такі: «забезпечує більш якісні аудіо та відеосигнали у достатньо великих приміщеннях за участі великої кількості учасників»; «можна використовувати для проведення лекцій відомих учених і практиків, а також для проведення телемостів між університетами для встановлення та підтримки зв'язку між студентами та викладачами із різних університетів»; сприяє комунікації «одного із багатьма» (викладач-група студентів в аудиторії та у віртуальному просторі)»; є можливість «у реальних умовах (малознайома аудиторія, незвичний формат професійної комунікації), але у віртуальному середовищі практикувати уміння проведення презентацій, участі у дискусії»; «уміння проведення ділових зустрічей у віртуальному форматі»; «у студентів формується риторична культура»; «віртуальний бар'єр, відеокамера, невимушена атмосфера сприяє зняттю психологічної напруги 
у комунікантів»; «розвиток особистісних якостей студентів (гнучкість мислення, толерантність, креативність тощо)». До недоліків вчена уналежнює те, що «спілкування при такому виді зв'язку відбувається зазвичай нерівномірно, не встановлюється тісний контакт, не виникають довірливі стосунки між учасниками відеоконференцзв'язку»; «комунікація при цьому виді зв'язку є доволі офіційною за характером взаємодії» (Приходько А. М., 2015, с. 94).

О. Глазунова підкреслює необхідність 3-поміж чинних технологій е-навчання використовувати відеоконференцію, зокрема, й з використанням інтерактивної дошки для візуалізації матеріалу (Глазунова О. Г., 2017, с. 47). При цьому вчена зауважує, що добір і створення е-навчальних ресурсів, одним із яких є вебконференція, має базуватися на таких принципах, як-от: технологічності, гнучкості, модульності, доступності, індивідуальності (там само, с. 51). На думку О. Глазунової, принцип технологічності «реалізується через застосування форм, методів та засобів, які характерні для е-навчання та відповідають педагогічним технологіям веб-орієнтованого навчання», потреба в адаптуванні та реагуванні на сучасні зміни «у змісті, технологіях навчання, навчального стилю студентів вимагають дотримання принципу гнучкості при формуванні змістових елементів електронного навчального курсу», принцип індивідуальності імплементується в освітній процес «через побудову індивідуальної траєкторії навчання студентів, що підвищує рівень диференційованого навчання, яке враховує індивідуальні особливості студентів», принцип модульності «враховується при побудові модульної структури електронного навчального курсу», принцип доступності «передбачає врахування рівня розвитку індивідуальних, вікових особливостей студентів, дотримання правил: від простого - до складного, від відомого - до невідомого, від близького - до далекого».

О. Словінська наголошує, що «впровадження онлайн-заходів, зокрема вебконференцій, у технології е-lеarning дають змогу зробити освітній процес: зручним і комфортним з точки зору створення умов для освоєння матеріалу; персоналізованим у плані вибору рівня складності, часу й обсягу освоєння навчального матеріалу; інтерактивним, тому що можна навчатися за допомогою синхронного та асинхронного взаємодії з викладачем та однокурсниками» (Словінська О. Д., 2015, с. 89). При цьому акцентується увага, що «правильне використання та застосування в галузях освітньої діяльності засобів організації вебконференцій забезпечує інтенсифікацію всіх рівнів навчально-виховного процесу, інтерактивність наукового процесу та зворотний зв'язок між обома сторонами навчального процесу» (Словінська О. Д., 2015 , с. 90). Крім того, до переваг залучення вебконференцій у науково-педагогічну діяльність вона уналежнює такі, як можливість «покращити менеджмент публікацій, підвищити ефективність навчально-дослідного процесу на всіх рівнях організації, інтенсифікувати когнітивну діяльність та підвищити її результативність» (Словінська О. Д., 2015, с. 90).

Одними із засобів проведення вебконференцій є програми Skype i Zoom, додаток до мобільного телефону Viber, безкоштовний месенджер Discord, що був на початку розроблений з метою його використання користувачами комп'ютерних ігор; вони дають можливість шляхом їх застосування впроваджувати всі можливі способи проведення вебконференцій.

Комп'ютерна програма Skype, на думку А. Приходько, заслуговує на увагу з метою інтенсифікації освітнього процесу з іншомовної підготовки студентів, оскільки встановлює миттєвий відеозв'язок із абонентом. Учений відзначає, що «проведення відеоконференцій за допомогою зазначеної програми не потребує від викладача та студентів особливих навичок використання інтернет-технологій у навчальному процесі, що суттєво полегшує процес підготовки, проведення та аналізу такої форми роботи» (Приходько А. М., 2015, с. 94). Як влучно зазначає П. Лозинський, «інтеграція Skype в навчальний процес дає змогу ефективніше вирішувати цілий ряд дидактичних завдань на занятті таких, як формувати і вдосконалювати навички читання, письма, говоріння та аудіювання, уміння діалогічного мовлення, поповнювати словниковий запас (активний і пасивний) лексикою сучасної іноземної мови, знайомити курсантів із соціокультурними реаліями мови, що вивчається (мовний етикет, особливості мовної поведінки, особливості культури, традиції країни, мова якої вивчається)» (Лозинський П. І., 2015, с. 233). При цьому варто зауважити, що, на противагу програмі Skype і месенджеру Discord, програма Zoom обмежує час групової конференції, яка включає понад двох учасників до 40 хвилин. Водночас вони всі підходять як для реалізації індивідуальних, так і для групових занять. Для індивідуальних занять у форматі відеоконференції можна використовувати також програму Messenger, що розроблена Facebook.

Розглянемо варіанти проведення вебконференції з використанням програми Zoom для іншомовної підготовки студентів. Так, при вивченні теми «Проблеми іншомовного спілкування з іноземцем у сучасному світі» студентам може бути запропоноване заняття у вигляді вебконференції для формування іншомовної лексичної компетенції, а також іншомовної компетенції в говорінні. Заздалегідь студенти готують повідомлення у вигляді презентації на запропоновані викладачем теми. На практичному занятті вони представляють проблеми, з якими може зіштовхнутися людина при спілкуванні з іноземцем (наприклад: соціально-культурний бар'єр розуміння; етика спілкування; мовний (комунікативний) бар'єр тощо). Наприкінці такого заняття викладач за допомогою чату, який містить програма Zоот, пропонує студентам відповісти на низку тестових завдань з пройденої теми, зокрема, можливим є залучення вправ «True (T) or False (F)», «Mind-тар» тощо.

\section{ВИСНОВКИ ТА ПЕРСПЕКТИВИ ПОДАЛЬШИХ ДОСЛІДЖЕНЬ}

Аналіз передових наукових розвідок та досвід практичного використання відеоконференцій для організації іншомовної підготовки студентів уможливлює констатувати, що до переваг використання відеоконференцій належить:

1) створення рівних можливостей доступу до взаємодії студентів та викладачів (зокрема, комунікативної взаємодії іноземною мовою) незалежно від місця їх перебування в зручний для кожного учасника вебконференції час;

2) реалізація студентоцентрованого навчання і викладання, у межах якого всі зусилля спрямовуються на забезпечення кожного студента окремо і всіх разом необхідною інформацією в режимі онлайн; 
3) наявність постійного зворотного зв'язку між усіма суб'єктами освітнього процесу (як завдяки діалогу між учасниками в ході конференції, так і шляхом залучення під час конференції чату);

4) розширення доступу до освітніх ресурсів за наставництва викладача і обміну інформацією онлайн; гнучкість для того, хто навчається, унаслідок можливості цілодобового доступу до інформації в режимі реального часу (у будь-який час і в будь-якому місці);

5) візуалізація освітнього процесу онлайн (бачити, чути співрозмовника (як викладача, так і усіх студентів), а також пропоновану викладачем інформацію, активно комунікувати, що важливо для іншомовної підготовки);

6) одночасне залучення значного числа учасників із різних регіонів України і зарубіжжя.

Таким чином, використання відеоконференції у закладах вищої освіти підвищує ефективність професійної підготовки майбутніх фахівців, зокрема іншомовної. Перспективним $є$ дослідження можливостей комбінування різного роду новітніх засобів навчання під час проведення вебконференцій (залучення мультимедійних дощок, проекторів тощо) задля забезпечення якості іншомовної підготовки студентів закладів вищої освіти.

\section{СПИСОК ВИКОРИСТАНИХ ДЖЕРЕЛ}

Глазунова, О. Г. (2017). Методологічні засади створення та використання електронних навчальних ресурсів в системі вищої освіти. Інформаційні технології в економіці і природокористуванні, 2, 45-55. URL: http://journals.nubip.edu.ua/index.php/Inf/article/ viewFile/9743/8711

Дідух, Л. І. (2012). Використання соціальних мереж для формування готовності до професійного спілкування. Інформаційно-комунікаційні технології в сучасній освіті: досвід, проблеми, перспективи: збірник наукових праць третьої Міжнародної науково-практичної конференції. ЛДУБЖД. URL: http://virt.ldubgd.edu.ua/konferenc/kon_ikt/sekziya2/Didych.pdf

Жарких, Ю. С., Лисоченко, С. В., Сусь, Б. Б., Третяк, О. В. (2012). Комп'ютерні технології в освіті: навчальний посібник. Київ: Видавничо-поліграфічний центр «Київський університет».

Задорожна, І. (2013). Організаційні форми і засоби реалізації самостійної роботи майбутніх учителів іноземних мов. Людинознавчі студії. Педагогіка, 27, 59-72. URL: http://nbuv.gov.ua/UJRN/Lstud_2013_27_7

Лисенко, Л. О. (2019). Використання ІТ-технологій при вивченні англійської мови за професійним спрямуванням. Наукові записки. Серія: Педагогічні науки, 178, 125-128.

Лозинський, П. І. (2015). Використання комп'ютерної програми Skyре на заняттях іноземної мови. Вісник Житомирського державного університету. Філологічні науки, 1 (79), $230-235$.

Приходько, А. М. (2015). Відеоконференція як засіб формування професійно-комунікативної компетентності іноземних студентів вищих технічних навчальних закладів. Вісник Черкаського університету. Серія «Педагогічні науки», 32 (365), 92-96.

Словінська, О. Д. (2015). Науково-організаційні засади та чинники доцільності використання систем веб-конференцій як новітніх електронних засобів навчання. Теорія і практика управління соціальними системами, 3, 87 - 92.

Basko, L., Hartman, J. (2017). Increasing student engagement through paired technologies. Grand Canyon University. Journal of Instructional Research, 6, 24-28. URL: https://files.eric.ed.gov/fulltext/EJ1152968.pdf

Soter, M. (2020). Using Zoom in Ukrainian technical higher education institutions. Modern approaches to the introduction of science into practice: the X-th International scientific and practical conference. Abstracts of X International Scientific and Practical Conference. San Francisco, USA.

\section{REFERENCES}

Hlazunova, O. H. (2017). Metodolohichni zasady stvorennia ta vykorystannia elektronnykh navchalnykh resursiv $v$ systemi vyshchoi osvity. Information technologies in economics and nature management, 2, 45-55. Retrieved from: http://journals.nubip.edu.ua/index.php/In/article/ viewFile/9743/8711

Didukh, L. I. (2012). Vykorystannia sotsialnykh merezh dlia formuvannia hotovnosti do profesiinoho spilkuvannia. Information and communication technologies in modern education: experience, problems, prospects: Proceedings of the 3rd International Scientific-Practical Conference. Retrieved from: http://virt.Idubgd.edu.ua/konferenc/kon_ikt/sekziya2/Didych.pdf

Zharkykh, Yu. S., Lysochenko, S. V., Sus, B. B., Tretiak, O. V. (2012). Kompiuterni tekhnolohii v osviti. Kyiv.

Zadorozhna, I. (2013). Orhanizatsiini formy i zasoby realizatsii samostiinoi roboty maibutnikh uchyteliv inozemnykh mov. Human Studies. Series of Pedagogy, 27, 59-72. Retrieved from: http://nbuv.gov.ua/UJRN/Lstud_2013_27_7

Lysenko, L. O. (2019). Vykorystannia IT-tekhnolohii pry vyvchenni anhliiskoi movy za profesiinym spriamuvanniam. Scientific Proceedings. Series: Pedagogical Sciences, 178, 125-128.

Lozynskyi, P. I. (2015). Vykorystannia kompiuternoi prohramy Skype na zaniattiakh inozemnoi movy. Zhytomyr State University Journal, Philological sciences, 1 (79), 230-235.

Prykhodko, A. M. (2015). Videokonferentsiia yak zasib formuvannia profesiino-komunikatyvnoi kompetentnosti inozemnykh studentiv vyshchykh tekhnichnykh navchalnykh zakladiv. Bulletin of Cherkasy University, Series: Pedagogical Sciences, 32 (365), 92-96.

Slovinska, O. D. (2015). Naukovo-orhanizatsiini zasady ta chynnyky dotsilnosti vykorystannia system veb-konferentsii yak novitnikh elektronnykh zasobiv navchannia. Theory and practice of social systems management, 3, 87-92.

Basko, L., Hartman, J. (2017). Increasing student engagement through paired technologies. Grand Canyon University. Journal of Instructional Research, 6, 24-28. Retrieved from: https://files.eric.ed.gov/fulltext/EJ1152968.pdf

Soter, M. (2020). Using Zoom in Ukrainian technical higher education institutions. Modern approaches to the introduction of science into practice: the $X$-th International scientific and practical conference. Abstracts of X International Scientific and Practical Conference. San Francisco, USA. 